\title{
Study on Energy Saving Application Strategy of New Residential Houses Envelope Structure in Sanjiangyuan Area Based on Dest Orthogonal Simulation
}

\author{
YuehengTong ${ }^{1, *}$, Yang Chen $^{1}$, and Wubing Shao ${ }^{2}$ \\ ${ }^{1}$ School of Human Settlements and Civil Engineering, Xi' an Jiaotong University, Xi'an 710049, China \\ ${ }^{2}$ School of art and design, Wuhan university of technology, Wuhan 430070, China
}

\begin{abstract}
With the rapid development of social economy, the problem of energy is becoming more and more serious, building energy conservation has become the top priority. Considering the abundant solar energy resources in the Sanjiangyuan area, this paper takes reduce the energy consumption of local residential noumena as the objective, and takes energy consumption of residential system as research target. Taking the modern dwellings in the Sanjiangyuan area as an example, to build a typical model, using the Dest software developed by Tsinghua University to dynamically simulate the load variation of building envelope caused by windows, exterior walls, window wall ratio and roof, and 16 orthogonal test results are simulated. Through the simulation analysis of the upper floors of the building, this study explores the changes in the influence of the form of the envelope structure on the building, then analyse the sensitivity of each factor affecting building energy consumption, and find out the optimal scheme of the envelope in the locality. Finally, this paper suggests that the energy conservation of new residential buildings in Sanjiangyuan area should strengthen the thickness of thermal insulation layer of envelop, open large windows in the south, open small windows in the north, and choose energy saving windows with low heat transfer coefficient to reduce energy consumption and save energy.
\end{abstract}

\section{Introduction}

In recent years, China's construction industry has developed rapidly, and building energy consumption has increased. In response to national sustainable development policies, passive design through buildings is the most effective way to reduce building energy consumption. The building envelope is the key to building energy efficiency, which consumes about $40 \%$ of the building's energy consumption ${ }^{[1]}$. Therefore, in the primary planning stage of the building, the analysis of the influence of the single factors of the building envelope on the building load is the key to the energy saving of the building body. Taking a pre-existing new dwelling in Sanjiangyuan as an example, this paper uses the Dest software to simulate the energy consumption of the building envelope structure, and conducts multifactor coupling analysis through orthogonal experiment to obtain the application of the envelope structure suitable for the new dwellings in the Sanjiangyuan area.

\section{Analysis of Factors Affecting Energy Saving of Building Envelope Structure}

To study the impact of building envelope structure on residential energy consumption, the impact of building thermal energy consumption on transparent envelope structure, exterior wall and roof should be considered.

\subsection{Transparent Envelope}

As the main part of the envelope structure, the transparent envelope structure not only provides natural lighting and visual field functions, but also is the main part of indoor and outdoor heat exchange. After conversion, the energy consumption of the transparent envelope structure is about $40 \%$ to $50 \%$ of the total energy consumption of the building's external protective structure ${ }^{[2]}$. At the same time, the glass material accounts for more than $70 \%$ of the transparent envelope structure, and its heat transfer coefficient directly determines the energy consumption of the transparent envelope structure. According to the thermal partition of the building and its design requirements, the influence of the ratio of window to wall in the Sanjiangyuan area on the thermal load of the building in winter is two-way. The window-to-wall ratio will affect the heat exchange from the indoor space and cause heat exchange between the indoor and outdoor ${ }^{[3]}$. In addition, the orientation of the windows can also affect the difference in energy consumption of residential buildings ${ }^{[4]}$. 


\subsection{Exterior wall}

The outer wall accounts for the largest part of the envelope structure, accounting for about $43 \%$ of the energy consumption of the envelope structure ${ }^{[5]}$. In the Sanjiangyuan area, the external wall insulation technology is an effective measure to reduce the energy consumption of residential buildings, and the thermal insulation performance of the external wall also plays a decisive role in the overall energy consumption of the building. Wall insulation materials can effectively solve the problem of cold and heat bridges and reduce building energy consumption.

\subsection{Roof}

The proportion of the roof to the building envelope is smaller than that of the transparent enclosure and the external wall, accounting for about $12 \%$ of the energy consumption of the enclosure ${ }^{[5]}$. However, the thermal performance of the roof plays a vital role in the indoor thermal environment of the roof room, which can effectively reduce the load on the roof of the building envelope.

\section{Building simulation analysis}

\subsection{Model establishment}

The Sanjiangyuan area is located in the severe cold C area, with short summer time and long winter time. This paper selects a new residential house in the Sanjiangyuan area as a simulation object. The building area is $193.3 \mathrm{~m} 2$ and the height is $3 \mathrm{~m}$, facing north and south. The setting of the indoor thermal disturbance mode of the model is set according to the software default value. The ratio of window to wall in the east and west is 0.1 , the number of indoor air changes is 0.5 per hour, and the heating period is from October 15 to April 15. The residential model plane is shown in Figure 1, and the enclosure structure is constructed as shown in Table 1.

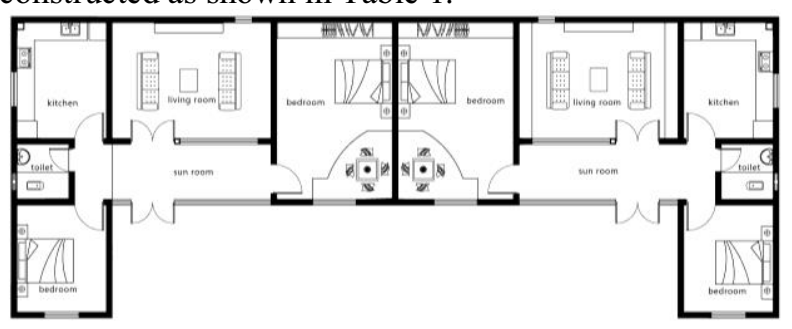

Fig. 1. Building layout.

Table 1. Envelope structure.

\begin{tabular}{|c|c|}
\hline Structure & Material name \\
\hline Exterior wall & $\begin{array}{c}20 \mathrm{~mm} \text { cement mortar }+30 \mathrm{~mm} \text { EPS thermal } \\
\text { insulation mortar }+20 \mathrm{~mm} \text { cement } \\
\text { mortar }+240 \mathrm{~mm} \text { concrete perforated brick }\end{array}$ \\
\hline Interior wall & $\begin{array}{c}20 \mathrm{~mm} \text { cement mortar }+180 \mathrm{~mm} \text { ceramsite } \\
\text { concrete }+20 \mathrm{~mm} \text { cement mortar }\end{array}$ \\
\hline Roof & $200 \mathrm{~mm}$ RC $+28 \mathrm{~mm}$ EPS \\
\hline Floor & $20 \mathrm{~mm}$ extruded polystyrene board $+120 \mathrm{~mm} \mathrm{RC}$ \\
\hline
\end{tabular}

\subsection{Combination scheme of building envelope}

According to the analysis of the factors affecting the energy saving of residential building envelopes, the glass type(I), the south window ratio(II), the north window ratio(III), the roof insulation thickness(IV) and the outer wall insulation thickness(V)are selected as the main envelope structure indicators. According to the relevant standards of JGJ26-2018“Design Standards for Energy Efficiency of Residential Buildings in Severe Cold and Cold Areas", each factor takes 4 standards and is studied by orthogonal experiment method, as shown in Table 2 and Table 3.

Table 2. Simulated factor selection

\begin{tabular}{|c|c|c|c|c|c|}
\hline $\begin{array}{c}\text { Standar } \\
\mathrm{d}\end{array}$ & $\begin{array}{l}\text { Glass } \\
\text { type I }\end{array}$ & $\begin{array}{c}\text { South } \\
\text { facing } \\
\text { windo } \\
\text { w } \\
\text { ratiolI }\end{array}$ & $\begin{array}{c}\text { North } \\
\text { facing } \\
\text { windo } \\
\text { w ratio } \\
\text { III }\end{array}$ & $\begin{array}{c}\text { Roof } \\
\text { insulatio } \\
n \\
\text { thicknes } \\
\text { s IV/ } \\
(\mathrm{mm})\end{array}$ & $\begin{array}{l}\text { External wall } \\
\text { insulation } \\
\text { thickness } \mathrm{V} /(\mathrm{m} \\
\mathrm{m})\end{array}$ \\
\hline 1 & $\begin{array}{l}\text { Ordinar } \\
\text { y single- } \\
\text { layer } \\
\text { glass }\end{array}$ & 0.15 & 0.1 & 40 & 40 \\
\hline 2 & $\begin{array}{l}\text { Ordinar } \\
\mathrm{y} \\
\text { insulatin } \\
\text { g glass }\end{array}$ & 0.25 & 0.15 & 50 & 60 \\
\hline 3 & $\begin{array}{l}\text { Double } \\
\text { hollow } \\
\text { low-E } \\
\text { glass }\end{array}$ & 0.35 & 0.2 & 60 & 80 \\
\hline 4 & $\begin{array}{l}\text { Ordinar } \\
\text { y triple } \\
\text { glass } \\
\text { insulatin } \\
\text { g glass }\end{array}$ & 0.45 & 0.25 & 70 & 100 \\
\hline
\end{tabular}

Table 3. Glass type and heat transfer coefficient.

\begin{tabular}{|c|c|}
\hline Glass type & $\begin{array}{c}\text { Heat transfer coefficient } \\
\mathrm{K} /\left(\mathrm{W} / \mathrm{m}^{2}\right)\end{array}$ \\
\hline $\begin{array}{c}\text { Ordinary single-layer glass } \\
(6 \mathrm{C})\end{array}$ & 5.7 \\
\hline $\begin{array}{c}\text { Ordinary insulating glass } \\
(6+9 \mathrm{~A}+6)\end{array}$ & 3.1 \\
\hline $\begin{array}{c}\text { Double hollow low-E glass } \\
\text { (6Low }-\mathrm{E}+9 \mathrm{~A}+6)\end{array}$ & 2.1 \\
\hline $\begin{array}{c}\text { Ordinary triple glass } \\
\text { insulating glass } \\
(6 \mathrm{C}+9 \mathrm{~A}+6 \mathrm{C}+9 \mathrm{~A}+6 \mathrm{C})\end{array}$ & 2.3 \\
\hline
\end{tabular}

According to the above-mentioned horizontal values, this paper simulates according to the L16(4 $\left.4^{5}\right)$ type orthogonal experimental table, and calculates the annual energy consumption of each scheme in the building, and the influence between each factor is not considered. And the simulation data is shown in Table 4.

Table 4. Orthogonal experimental table and simulation data.

\begin{tabular}{|c|c|c|c|c|c|}
\hline I & II & III & IV & V & $\begin{array}{c}\text { Heating season heat } \\
\text { load index W/m }{ }^{2}\end{array}$ \\
\hline $\begin{array}{c}\text { Ordinary single-layer } \\
\text { glass }\end{array}$ & 0.15 & 0.1 & 40 & 40 & 79.51 \\
\hline $\begin{array}{c}\text { Ordinary single-layer } \\
\text { glass }\end{array}$ & 0.25 & 0.15 & 50 & 60 & 73.82 \\
\hline $\begin{array}{c}\text { Ordinary single-layer } \\
\text { glass }\end{array}$ & 0.35 & 0.2 & 60 & 80 & 71.45 \\
\hline
\end{tabular}




\begin{tabular}{|c|c|c|c|c|c|}
\hline $\begin{array}{c}\text { Ordinary single-layer } \\
\text { glass }\end{array}$ & 0.45 & 0.25 & 70 & 100 & 71.15 \\
\hline $\begin{array}{c}\text { Ordinary insulating } \\
\text { glass }\end{array}$ & 0.15 & 0.15 & 60 & 100 & 53.57 \\
\hline $\begin{array}{c}\text { Ordinary insulating } \\
\text { glass }\end{array}$ & 0.25 & 0.1 & 70 & 80 & 51.23 \\
\hline $\begin{array}{c}\text { Ordinary insulating } \\
\text { glass }\end{array}$ & 0.35 & 0.25 & 40 & 60 & 62.83 \\
\hline $\begin{array}{c}\text { Ordinary insulating } \\
\text { glass }\end{array}$ & 0.45 & 0.2 & 50 & 40 & 62.56 \\
\hline $\begin{array}{c}\text { Double hollow low-E } \\
\text { glass }\end{array}$ & 0.15 & 0.2 & 70 & 60 & 54.06 \\
\hline $\begin{array}{c}\text { Double hollow low-E } \\
\text { glass }\end{array}$ & 0.25 & 0.25 & 60 & 40 & 57.82 \\
\hline $\begin{array}{c}\text { Double hollow low-E } \\
\text { glass }\end{array}$ & 0.35 & 0.1 & 50 & 100 & 47.77 \\
\hline $\begin{array}{c}\text { Double hollow low-E } \\
\text { glass }\end{array}$ & 0.45 & 0.15 & 40 & 80 & 46.11 \\
\hline $\begin{array}{c}\text { Ordinary triple glass } \\
\text { insulating glass }\end{array}$ & 0.15 & 0.25 & 50 & 80 & 56.94 \\
\hline $\begin{array}{c}\text { Ordinary triple glass } \\
\text { insulating glass }\end{array}$ & 0.25 & 0.2 & 40 & 100 & 54.09 \\
\hline $\begin{array}{c}\text { Ordinary triple glass } \\
\text { insulating glass }\end{array}$ & 0.35 & 0.15 & 70 & 40 & 56.96 \\
\hline $\begin{array}{c}\text { Ordinary triple glass } \\
\text { insulating glass }\end{array}$ & 0.45 & 0.1 & 60 & 60 & 50.03 \\
\hline
\end{tabular}

\section{Analysis of energy consumption impact of envelope structure and Optimal combination scheme}

Perform orthogonal analysis on the simulated data in 16 schemes, and add the simulation results of different levels of each factor separately according to the selected factor, and obtain the sum of each standard, namely $\mathrm{K}_{1}$, $\mathrm{K}_{2}, \mathrm{~K}_{3}, \mathrm{~K}_{4}$ in Table 5. Then, use the formula (1) to calculate the difference values of $\mathrm{K}_{1}, \mathrm{~K}_{2}, \mathrm{~K}_{3}$, and $\mathrm{K}_{4}$.

$R_{I}=\max \left\{K_{I 1}, K_{I 2}, K_{I 3}, K_{I 4}\right\}-\min \left\{K_{I 1}, K_{I 2}, K_{I 3}, K_{I 4}\right\}$

$R_{I I}=\max \left\{K_{I I 1}, K_{I I 2}, K_{I I 3}, K_{I I 4}\right\}-\min \left\{K_{I I}, K_{I I 2}, K_{I I 3}, K_{I I 4}\right\}$

$R_{I I I}=\max \left\{K_{I I I 1}, K_{I I I 2}, K_{I I I 3}, K_{I I I 4}\right\}-$

$\min \left\{K_{I I I 1}, K_{I I I 2}, K_{I I I 3}, K_{I I I 4}\right\}$

$R_{I V}=\max \left\{K_{I V 1}, K_{I V 2}, K_{I V 3}, K_{I V 4}\right\}-\min \left\{K_{I V 1}, K_{I V 2}, K_{I V 3}, K_{I V 4}\right\}$

$R_{V}=\max \left\{K_{V 1}, K_{V 2}, K_{V 3}, K_{V 4}\right\}-\min \left\{K_{V 1}, K_{V 2}, K_{V 3}, K_{V 4}\right\}$

From the conclusion of the orthogonal test range analysis method, when the maximum difference of a column indicates that the value of the column changes within the test range, the variation of the test index value is maximized. Through the analysis of Table 5 , it can be found that $\mathrm{R}_{\mathrm{I}}>\mathrm{R}_{\mathrm{V}}>\mathrm{R}_{\mathrm{III}}>\mathrm{R}_{\mathrm{II}}>\mathrm{R}_{\mathrm{IV}}$, which means that the primary and secondary order of influence of each factor on the energy consumption of residential buildings is I, V, III, II, IV.

Table 5. Orthogonal experimental results.

\begin{tabular}{|c|c|c|c|c|c|}
\hline & I & II & III & IV & V \\
\hline $\begin{array}{c}\text { The } \\
\text { sum of } \\
\mathrm{K}_{1}\end{array}$ & 295.93 & 244.08 & 228.54 & 242.54 & 256.85 \\
\hline $\begin{array}{c}\text { The } \\
\text { sum of } \\
\mathrm{K}_{2}\end{array}$ & 230.19 & 236.96 & 230.46 & 241.09 & 240.74 \\
\hline $\begin{array}{c}\text { The } \\
\text { sum of } \\
\mathrm{K}_{3}\end{array}$ & 205.76 & 239.01 & 242.16 & 232.87 & 225.73 \\
\hline $\begin{array}{c}\text { The } \\
\text { sum of } \\
\mathrm{K}_{4}\end{array}$ & 218.02 & 229.85 & 248.74 & 233.4 & 226.58 \\
\hline
\end{tabular}

\begin{tabular}{|c|c|c|c|c|c|}
\hline $\begin{array}{c}\text { range } \\
\mathrm{R}\end{array}$ & 90.17 & 14.23 & 20.2 & 9.67 & 31.12 \\
\hline
\end{tabular}

According to the primary and secondary order of the factors determined by the above range, among the main factors of the residential building envelope in the severe cold area of Sanjiangyuan, the most important protective structure for the residential building energy is the glass material, followed by the insulation thickness of the external wall. Finally, the window and wall ratio and the thickness of the roof insulation. At the same time, because the optimization of the selection factor is related to the standard established, this paper discusses the problem of building heating energy consumption. Therefore, the smaller the heating season heat load index, the smaller the building energy consumption, that is, the smaller the amount of coal consumed, the more energysaving the scheme. Thus, the lowest number of heat load index results is selected as the optimal solution. From $\mathrm{K}_{1 \mathrm{II}}>\mathrm{K}_{2 \mathrm{I}}>\mathrm{K}_{4 \mathrm{I}}>\mathrm{K}_{3 \mathrm{II}}, \mathrm{K}_{1 \mathrm{II}}>\mathrm{K}_{3 \mathrm{II}}>\mathrm{K}_{2 \mathrm{II}}>\mathrm{K}_{4 \mathrm{II}}, \mathrm{K}_{4 \mathrm{III}}>\mathrm{K}_{3 \mathrm{III}}>\mathrm{K}_{2 \mathrm{III}}>$ $\mathrm{K}_{1 I I I}, \quad \mathrm{~K}_{1 \mathrm{IV}}>\mathrm{K}_{2 \mathrm{IV}}>\mathrm{K}_{4 \mathrm{IV}}>\mathrm{K}_{3 \mathrm{IV}}, \quad \mathrm{K}_{1 \mathrm{~V}}>\mathrm{K}_{2 \mathrm{~V}}>\mathrm{K}_{4 \mathrm{~V}}>\mathrm{K}_{3 \mathrm{~V}}$, the optimal solution for this experiment is I3II4III1IV3V3. The glass material is selected from double-layer low-E glass, the ratio of the south facing window to wall is 0.45 , the ratio of the north facing window to wall is 0.1 , the wall insulation material is $80 \mathrm{~mm}$ EPS, and the roof insulation material is $60 \mathrm{~mm}$ EPS insulation board.

\section{Conclusion}

Through orthogonal experimental simulation, the influence of five main factors on the thermal load of the building envelope was compared, and the material of the transparent envelope was determined to be the most important, followed by the wall insulation thickness, and finally the window-to-wall ratio and the roof insulation thickness. Under the premise of not considering economic conditions, in order to reduce the energy consumption of local buildings, the design of residential buildings in Sanjiangyuan area should use a transparent envelope with low heat transfer coefficient to increase the area of south facing windows and reduce the area of north facing windows. In addition, the thickness of the external wall and roof insulation should be reasonably increased.

\section{Acknowledgments}

This work was supported by the key research and development project of the Science and Technology Department of Qinghai Province (2018-S-5). The author would like to thank the reviewers for their helpful comments and suggestions.

\section{References}

1. Li Deying, Xu Wenfa. Building energy saving technology. Beijing: China Machine Press. (to be published)

2. Zhang Yunxia, Zhu Kun. Research and application status of energy-saving Windows and existing 
problems are discussed. Energy and Environment. 14,3(2008)

3. Li Baoxin, Lu Yan. Analysis of the influence of window area ratio on building energy consumption in cold areas. Construction Science and Technology. 39,20(2012)

4. Jin Guohui, Zhao Xijian. Orthogonal Simulation of the Potential Energy Saving of Residential Buildings Palisade Structure in Hubaoe Region Based on DeST. Journal of Civil Engineering and Management. 64,6(2016)

5. Li Baoxia. Several exterior wall insulation and energy saving technologies. China Construction. 43,7(2008) 